\title{
BISNIS KOSMETIK DALAM ETIKA BISNIS ISLAM
}

\author{
Orin Oktasari \\ Sekolah Tinggi Ilmu Ekonomi Syariah Nahdatul Ulama (STIESNU) Bengkulu \\ Email: chibana.orin@gmail.com
}

\begin{abstract}
Cosmetic Business in Islamic Business Ethics, The cosmetics business is a series of businesses in various forms of cosmetic products that are in use for improve the appearance or aroma of the human body. Business activities are muamalah activities, which Muslims in various activities must always adhere to divine norms. So in the cosmetic business activity is basically allowed according to the rules of muamalah, This is as the law of origin rather than using something is mubah, related to cosmetics, Islam does not want anything harmful to its users because something that is harmful is forbidden. But in practice cosmetics business is also a lot of cosmetics that are not feasible circulation because the substances contained in these cosmetics contain harmful ingredients have a negative impact, that is: cause effects such as irritation, the emergence of reddish spots and black spots, acne, and other health disturbances when the use of long coats such as kidney failure and some other negative impact. Business Practice as above is a mal-business practice, which contains elements of al-bathil, al-fasad, and azh-zhalim. This can cause both material and immaterial losses to my cypress, other parties or the public. The principle of honesty and openness in business is the key to success. Transparency of the consumer is when a producer is open about quality, quantity, composition, chemical elements and others so as not to harm and harm consumers. Islam prohibits free competition that justifies any means because it is against the principles of muamalah.
\end{abstract}

Keywords: Business cosmetics, Islamic Business Ethics

Abstrak: Bisnis Kosmetik dalam Etika Bisnis Islam, Bisnis kosmetik merupakan serangkaian bisnis dalam berbagai bentuk produk-produk kosmetik yang di gunakan untuk meningkatkan penampilan atau aroma tubuh manusia. Kegiatan bisnis merupakan kegiatan muamalah, yang mana umat Islam dalam berbagai aktivitasnya harus selalu berpegang dengan norma-norma ilahiyah. Jadi dalam kegiatan bisnis kosmetik pada dasarnya adalah boleh sesuai dengan kaidah muamalah, Hal ini sebagaimana hukum asal dari pada memanfaatkan sesuatu adalah mubah, berkaitan dengan kosmetik, Islam tidak menghendaki adanya sesuatu yang membahayakan bagi penggunanya karena sesuatu yang membahayakan adalah terlarang. Namun pada prakteknya bisnis kosmetik juga banyak kosmetik yang tidak layak edar karena zat-zat yang terkandung dalam kosmetik tersebut mengandung bahan-bahan yang berbahaya memberikan dampak negatif yaitu: menimbulkan efek seperti iritasi, timbulnya bintikbintik kemerah-merahan flek-flek hitam, jerawat, serta gangguaan kesehatan lainnya apabila penggunaan janggka panjang seperti gagal ginjal dan beberapa dampak negatif lainnya. Praktek Bisnis seperti di atas merupakan praktek mal-bisnis, yang mengandung unsur al-bathil, al-fasad, dan azhzhalim. Hal ini dapat menimbulkan kerugian secara material maupun immateri baik sipelaku, pihak lain maupun masyarakat. Prinsip kejujuran dan keterbukaan dalam bisnis merupakan kunci keberhasilan. Apapun bentuknya, kejujuran tetap menjadi prinsip utama sampai saat ini. Transparansi terhadap kosumen adalah ketika seorang produsen terbuka mengenai mutu, kuantitas, komposisi, unsur-unsur kimia dan lain-lain agar tidak membahayakan dan merugikan konsumen. Islam melarang persaingan bebas yang menghalalkan segala cara karena bertentangan dengan prinsip-prinsip muamalah.

Kata Kunci: Bisnis kosmetik, Etika Bisnis Islam

\section{A. PENDAHULUAN}

Perkembangan produk kosmetik memberi peluang bisnis bagi para produsen kosmetik. Peluang bisnis tersebut menciptakan keanekaragaman produk kosmetik atau produk perawatan kulit yang kini beredar di pasar, yaitu dari produk tradisional sampai ke produk produk modern, sehingga konsumen dapat memilih produk kosmetik yang terbaik bagi dirinya, dan produk kosmetik tersebut dapat di peroleh dengan mudah di pusat-pusat perbelanjaan atau di media sosial bagi pelaku jual beli secara Online. 
Keinginan manusia untuk selalu tampil cantik, sempurna dalam segala kesempatan dimanfaatkan oleh sekelompok pelaku usaha yang tidak bertanggung jawab dengan memproduksi ataupun memperdagangkan kosmetik yang tidak memenuhi persyaratan kepada masyarakat. Sasaran utamanya adalah para kaum wanita yang ingin mendapatkan hasil yang cepat dan maksimal. Mereka akan mudah sekali tertarik untuk membeli produk kosmetik dengan harga yang murah dan cepat terlihat hasilnya. ${ }^{1}$ Hal ini yang membuat mereka mencari jalan alternatif dengan membeli produk tersebut walaupun mungkin tidak memenuhi persyaratan dan kosmetik tersebut dijual secara bebas di pasaran, dan tidak jarang produkproduk tersebut di beli konsumen karena cara promosi dari pelaku usaha yang menjanjikan membuat konsumen tertarik untuk membeli produk-produk kecantikan tersebut. Sedangkan Rasululllah SAW memberikan contoh bagaimana bersaing dengan baik dengan memberikan pelayanan sebaik-baiknya dan jujur dengan kondisi barang dagangan serta melarang kolusi dalam persaingan bisnis karena merupakan perbuatan dosa yang harus dijauhi.
Sebagaimana disebutkan dalam QS. Al Baqarah ayat 188 :

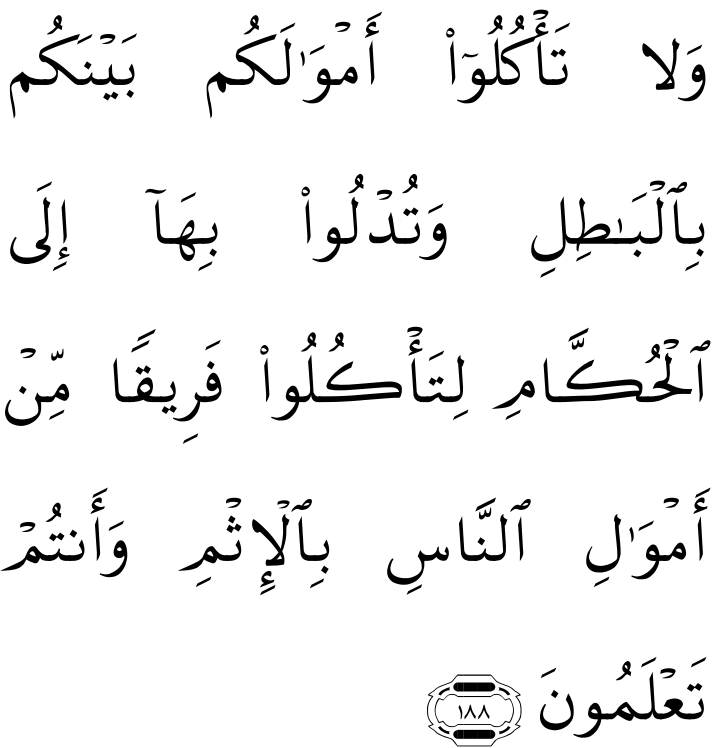

Artinya: "Dan janganlah sebahagian kamu memakan harta sebahagian yang lain di antara kamu dengan jalan yang batil dan (janganlah) kamu membawa (urusan) harta itu kepada hakim, supaya kamu dapat memakan sebahagian daripada harta benda orang lain itu dengan (jalan berbuat) dosa, padahal kamu mengetahui."

Pengelolaan bisnis dalam konteks pengelolaan secara etik mesti menggunakan landasan norma dan moralitas umum berlaku di masyarakat. Penilaian keberhasilan bisnis tidak saja ditentukan oleh keberhasilan prestasi ekonomi dan finansial semata tetapi keberhasilan itu diukur dengan tolok ukur paradigma moralitas dan nilai-nilai sosial dan agama. Tolok ukur ini harus menjadi bagian yang integral dalam menilai 
keberhasilan suatu kegiatan bisnis. ${ }^{2}$ Etika Bisnis Islam memiliki konsep Equilibrium (Keseimbangan) yakni konsep adil, dimensi horizontal, jujur dalam bertransaksi, tidak merugikan dan tidak dirugikan.

Islam memiliki pedoman mengarahkan umatnya untuk melaksanakan amalan. Pedoman tersebut adalah Alquran dan Sunnah Nabi Muhammad SAW. Sebagai sumber ajaran Islam setidaknya dapat menawarkan nilai-nilai dasar atau prinsip-prinsip umum yang penerapanya dalam bisnis disesuaikan dengan perkembangan zaman dan mempertimbangkan dimensi ruang dan waktu. Islam sering sekali dijadikan sebagai model tatanan kehidupan. Hal ini tentunya dapat dipakai untuk pengembangan lebih lanjut atas suatu tatanan kehidupan tersebut, termasuk tatanan kehidupan bisnis. $^{3}$ Alquran memberikan tuntunan visi dan misi yang jelas yaitu visi bisnis masa depan yang bukan semata- mata mencari keuntungan sesaat tetapi merugikan melainkan mencari keuntungan yang secara hakikat baik dan berakibat baik pula bagi kesudahannya (Pengaruhnya). Dalam tulisan ini penulis akan membahas mengenai bisnis kosmetik dalam perspektif etika bisnis Islam.

\section{B. KONSEP BISNIS DALAM ISLAM}

Bisnis merupakan suatu istilah untuk menjelaskan segala aktivitas berbagai institusi dari yang menghasilkan barang dan jasa yang perlu untuk kehidupan masyarakat sehari-hari. Secara umum bisnis diartikan sebagai suatu kegiatan yang dilakukan oleh manusia untuk memperoleh pendapatan atau penghasilan atau rizki dalam rangka memenuhi kebutuhan dan keinginan hidupnya dengan caramengelola sumber daya ekonomi secara efektif dan efisien. Adapun sektor-sektor ekonomi bisnis tersebut meliputi sektor pertanian, sektor industri, jasa, dan perdagangan. ${ }^{4}$

Lebih khusus Skinner mendefinisikan bisnis sebagai pertukaran barang, jasa, atau uang yang saling menguntungkan atau memberi manfaat. Menurut Anoraga dan Soegiastuti, bisnis memiliki makna dasar sebagai "the buying and selling of goods and services”. Adapun dalam pandangan Straub dan Attner, bisnis tak lain adalah suatu organisasi yang menjalankan aktivitas produksi dan penjualan barang-

$\begin{array}{ccc}{ }^{2} \text { Muslich, Etika } \quad \text { Bisnis } & \text { Islami, } \\ \text { (Yogyakarta:Ekonosia, 2004), h. 9 } & \\ { }^{3} \text { Muhammad, Etika } & \text { Bisnis } & \text { Islami, } \\ \text { (Yogyakarta: UPP AMP YKPN, 2004), h. 7 } & \end{array}$

\footnotetext{
${ }^{4}$ Manullang, M, Pengantar Bisnis, (Yogyakarta : Gadjah Mada University Press 2002), h. 32
} 
barang dan jasa-jasa yang diinginkan oleh konsumen untuk memperoleh profit. ${ }^{5}$

Adapun dalam Islam bisnis dapat dipahami sebagai serangkaian aktivitas bisnis dalam berbagai bentuknya yang tidak dibatasi jumlah (kuantitas) kepemilikan hartanya (barang/jasa) termasuk profitnya, namun dibatasi dalam cara perolehan dan pendayagunaan hartanya (ada aturan halal dan haram). ${ }^{6}$

Pengertian di atas dapat dijelaskan bahwa Islam mewajibkan setiap muslim khususnya, yang memiliki tanggungan untuk bekerja. Bekerja merupakan salah satu sebab pokok yang memungkinkan manusia memiliki harta kekayaan. Untuk memungkinkan manusia berusaha mencari nafkah, Allah Swt melapangkan bumi serta menyediakan berbagai fasilitas yang dapat dimanfaatkan untuk mencari rizki. Di samping anjuran untuk mencari rizki, Islam sangat menekankan (mewajibkan) aspek kehalalannya, baik dari sisi perolehan maupun pendayagunaannya (pengelolaan dan pembelanjaan).

Prinsip-prinsip etika bisnis yang berlaku dalam kegiatan bisnis yang baik sesungguhnya tidak bisa dilepaskan dari

${ }^{5}$ Yusanto, Muhammad Ismail dan Muhammad Karebet Widjajakusuma. 2002. Menggagas Bisnis Islami, (Jakarta: Gema Insani Press 2002), h. 15

${ }^{6}$ Yusanto, Muhammad Ismail dan Muhammad Karebet Widjajakusuma. 2002. Menggagas Bisnis Islami..., h. 18 kehidupan kita sebagai manusia, hal ini berarti bahwa prinsip-prinsip etika bisnis terkait erat dengan sistem nilai yang dianut oleh masing-masing masyarakat. Prinsip-prinsip etika bisnis yang berlaku di China akan sangat dipengaruhi oleh sistem nilai masyarakat China, sistem nilai masyarakat Eropa akan mempengaruhi prinsip-prinsip bisnis yang berlaku di Eropa. ${ }^{7}$

Dalam bisnis, Rasulullah selalu menerapkan prinsip customer oriented, yaitu prinsip bisnis yang selalu menjaga kepuasan pelanggan. Untuk melakukan prinsip tersebut Rasulullah menerapkan kejujuran, keadilan, serta amanah dalam melaksanakan kontrak bisnis. Jika terjadi perbedaan pandangan maka diselesaikan dengan damai dan adil tanpa ada unsurunsur penipuan yang dapat merugikan salah satu pihak.

Dampak dari prinsip yang diterapkan, para pelanggan Rasulullah SAW tidak pernah merasa dirugikan. Tidak ada keluhan tentang janji-janji yang diucapkan, karena barang-barang yang disepakati dalam kontrak tidak ada yang dimanipulasi atau dikurangi.

Untuk memuaskan pelanggan ada beberapa hal yang selalu Nabi perintahkan. Beberapa hal tersebut antara lain, adil dalam menimbang,

${ }^{7}$ Alma, Buchari dan Donni Juni Priansa, Manajemen Bisnis Syariah, (Bandung : Alfabeta 2009), h. 204 
menunjukkan cacat barang yang diperjual belikan, menjauhi sumpah dalam jual beli dan tidak mempraktekkan apa yang disebut dengan bai' Najasy yaitu memuji dan mengemukakan keunggulan barang padahal mutunya tidak sebaik yang dipromosikan, hal ini juga berarti membohongi pembeli.

Prinsip kejujuran dan keterbukaan dalam bisnis merupakan kunci keberhasilan. Apapun bentuknya, kejujuran tetap menjadi prinsip utama sampai saat ini. Transparansi terhadap kosumen adalah ketika seorang produsen terbuka mengenai mutu, kuantitas, komposisi, unsur-unsur kimia dan lainlain agar tidak membahayakan dan merugikan konsumen. Islam melarang persaingan bebas yang menghalalkan segala cara karena bertentangan dengan prinsip-prinsip muamalah Islam. Islam memerintahkan umatnya untuk berlombalomba dalam kebaikan, yang berarti bahwa persaingan tidak lagi berarti sebagai usaha mematikan pesaing lainnya, tetapi dilakukan untuk memberikan sesuatu yang terbaik bagi usahanya.

Rasululllah SAW memberikan contoh bagaimana bersaing dengan baik dengan memberikan pelayanan sebaikbaiknya dan jujur dengan kondisi barang dagangan serta melarang kolusi dalam persaingan bisnis karena merupakan perbuatan dosa yang harus dijauhi. Terwujudnya keadilan adalah misi diutusnya para Rasul. Setiap bentuk ketidak adilan harus lenyap dari muka bumi. Oleh karena itu, Nabi Muhammad SAW selalu tegas dalam menegakkan keadilan termasuk keadilan dalam berbisnis. Saling menjaga agar hak orang lain tidak terganggu selalu ditekankan dalam menjaga hubungan antara yang satu dengan yang lain sebagai bentuk dari keadilan. ${ }^{8}$

Keadilan kepada konsumen dengan tidak melakukan penipuan dan menyebabkan kerugian bagi konsumen. Wujud dari keadilan bagi karyawan adalah memberikan upah yang adil bagi karyawan, tidak mengekploitasinya dan menjaga hak-haknya.

Dalam kajian fikih Islam, kebenaran dan keakuratan informasi ketika sesorang pelaku usaha mempromosikan barang dagangannya menempati kajian yang sangat signifikan. Informasi yang harus diberikan pada pembeli tidak hanya berhubungan dengan kuantitas kualitas suatu barang, tetapi juga berkaitan dengan efek samping atau bahaya pemakaian, perlindungan terhadap kepercayaan agama tertentu, seperti informasi halal atau haramnya suatu produk. Resiko pemakaian barang akan dikenakan pada pelaku usaha sebagai

${ }^{8}$ Muslich, Etika Bisnis Islami..., h. 106 
penyebab (tasabbub) kerugian karena melanggar prinsip hati-hati ('adam alihtiyath) atau sewenang-wenang dalam penggunaan hak ( al-ta'ssuf fi al-isti'mal al-haq). ${ }^{9}$

\section{KONSEP KOSMETIK}

Menurut Kamus Besar Bahasa Indonesia, pengertian mengenai kosmetik yaitu: "Kosmetik adalah obat (bahan) untuk mempercantik wajah, kulit, rambut, dan sebagainya seperti bedak dan pemerah bibir". Sedangkan kosmetika adalah ilmu kecantikan, ilmu tata cara mempercantik wajah, kulit dan rambut. ${ }^{10}$

Berkaitan dengan hal tersebut, dalam Peraturan Menteri Kesehatan Republik Indonesia Nomor 1175/MenKes/PER/VIII/ 2010 tentang Notifikasi Kosmetika, menyebutkan juga mengenai pengertian kosmetik yaitu :

Kosmetik adalah bahan atau sediaan yang dimaksudkan untuk digunakan pada bagian luar tubuh manusia (epidermis, rambut, kuku, bibir, dan organ genital bagian luar) atau gigi dan membran mukosa mulut terutama untuk membersihkan, mewangikan, mengubah penampilan dan atau memperbaiki bau badan atau melindungi atau memelihara tubuh pada kondisi baik.

\footnotetext{
${ }^{9}$ Muhammad, Etika Bisnis Islami..., h. 204

${ }^{10}$ Poerwadarminta, Kamus Umum Bahasa Indonesia, (Jakarta:PT Intan Parawira 2003), cet-III, h. 617
}

Jadi, kosmetik merupakan zat perawatan yang digunakan untuk meningkatkan penampilan atau aroma tubuh. Jenis kosmetik meliputi krim perwartan kulit, losion, bedak, parfum, lipstik, perias muka dan mata, perawatan rambut, serta semua produk perlengkapan mandi.

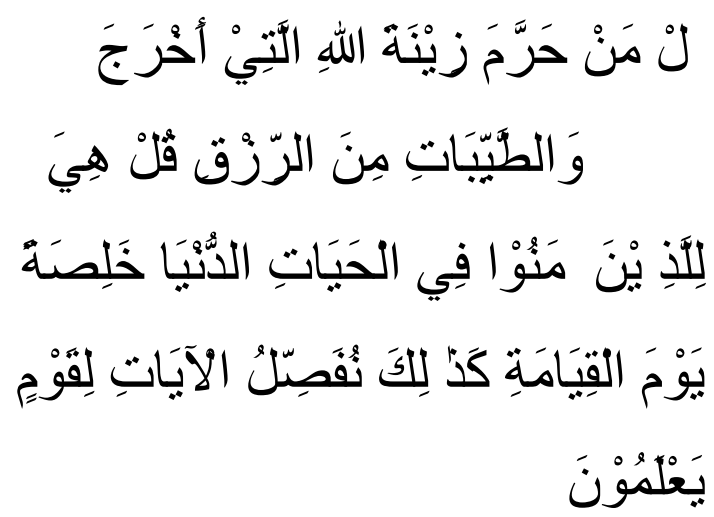

Artinya: katakanalah (Muhammad) "siapa yang mengharamkan perhiasan dari Allah yang telah disediakan untuk hamba-hambaNya dan rezeki yang baik-baik. Katakanlah semua itu untuk orang-orang yang beriman dalam kehidupan dunia, dan khusus (untuk mereka saja) pada hari kiamat. Demikianlah kami menjelaskan ayat-ayat itu untuk orang-orang yang mengetahui. (Q.S. Al-A'araf: 32)

Dalam surat Al-araf ayat 32 di atas, Allah membolehkan segala sesuatu yang bagus dalam kehidupan dan membolehkan bersenang-senang dengannya. Ayat tersebut sekaligus mengandung pengertian sekaligus bahwa seorang muslimah diperbolehkan menggunakan segala bentuk hiasan dan memanfaatkan segala bentuk yang bagus 
dalam kehidupan ini. ${ }^{11}$ Hal ini sebagaimana hukum asal dari pada memanfaatkan sesuatu adalah mubah. Sedangkan berkaitan dengan kosmetik , Islam tidak menghendaki adanya sesuatu yang membahayakan bagi penggunanya. Dalam sebuah kaidah "hukum asal dari sesuatu yang bermanfaat adalah mubah, sedangkan hukum asal dari sesuatu yang membahayakan adalah terlarang”.

\section{LANDASAN NORMATIF ETIKA BISNIS DALAM ISLAM}

Landasan normatif etika bisnis dalam Islam bersumber dari al-Qur'an dan Sunnah Nabi Muhammad SAW. Dalam konteks ini dapat dibagi menjadi empat kelompok, yaitu; landasan tauhid, landasan keseimbangan, landasan kehendak bebas, dan landasan pertanggungjawaban. ${ }^{12}$

\section{Tauhid (Kesatuan)}

Tauhid merupakan konsep serba eksklusif dan serba inklusif. Pada tingkat absolut ia membedakan khalik dengan makhluk, memerlukan penyerahan tanpa syarat kepada kehendak-Nya, tetapi pada eksistensi manusia memberikan suatu prinsip perpaduan yang kuat sebab seluruh umat manusia dipersatukan dalam ketaatan kepada Allah semata. Konsep

\footnotetext{
${ }^{11}$ Qamaruddin Awwam, Fiqh Wanita, (Jakarta: Cerdas Interaktif, 2017), h. 90

${ }^{12}$ Budi Untung, Hukum dan Etika Bisnis, (Yogyakarta :Penerbit CV Andi Offset, 2012), h. 125
}

tauhid merupakan dimensi vertikal Islam sekaligus horizontal yang memadukan segi politik, sosial ekonomi kehidupan manusia menjadi kebulatan yang homogen yang konsisten dari dalam dan luas sekaligus terpadu dengan alam luas. ${ }^{13}$

Dari konsepsi ini, maka Islam menawarkan keterpaduan agama, ekonomi, dan sosial demi membentuk kesatuan. Atas dasar pandangan ini maka pengusaha muslim dalam melakukan aktivitas maupun entitas bisnisnya tidak akan melakukan paling tidak tiga hal: Pertama, diskriminasi terhadap pekerja, penjual, pembeli, mitra kerja atas dasar pertimbangan ras, warna kulit, jenis kelamin atau agama (QS. Al Hujurat ayat 13).

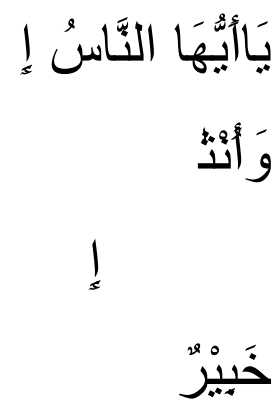

Artinya:"wahai manusia! sungguh, kami telah menciptakan kamu dari seorang laki-laki dan seorang perempuan, kemudian kami jadikan kamu berbangsa-bangsa dan bersuku-suku agar kamu saling mengenal. Sungguh, yang paling mulia diantara kamu disisi Allah ialah orang yang paling betaqwa.

\footnotetext{
${ }^{13}$ Muslich, Etika Bisnis Islami..., h. 224
} 
Sungguh, Allah Maha mengetahui, Maha teliti. (Q.S. Al-Hujurat ayat: 13)

Kedua, Allah lah semestinya yang paling ditakuti dan dicintai. Oleh karena itu, sikap ini akan terefleksikan dalam seluruh sikap hidup dalam berbagai dimensinya termasuk aktivitas bisnis (QS. Al An'aam ayat 163).$$
\text { شَرَكَ لَهُ وَبَّْ }
$$$$
\text { المُسنلِلِيْنَن }
$$

Artinya:"tidak ada sekutu bagi-Nya dan demikianlah yang diperintahkan kepadaku dan aku adalah orang yang pertama-tama berserah diri (muslim)." (Q.S. Al-An'am: 163)

Ketiga, menimbun kekayaan atau serakah, karena hakikatnya kekayaan merupakan amanah Allah (QS. Al Kahfi ayat 46).

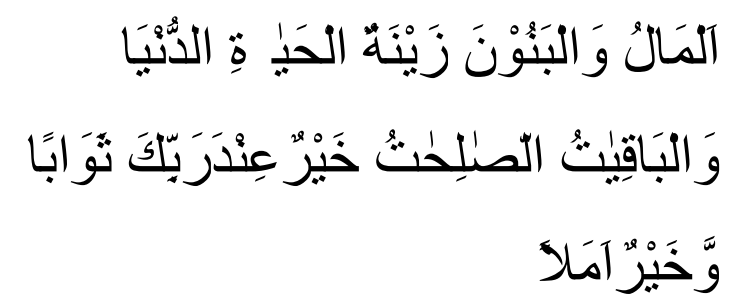

Artinya: "harta dan anak-anak adalah perhiasan kehidupan dunia tetapi amal kebajikan yang terus-menerus adalah lebih baik pahalanya di sisi Tuhanmu serta lebih baik untuk menjadi harapan." (Q.S. Al-Kahfi: 46).

2. Keseimbangan (Keadilan)
Ajaran Islam berorientasi pada terciptanya karakter manusia yang memiliki sikap dan prilaku yang seimbang dan adil dalam konteks hubungan antara manusia dengan diri sendiri, dengan orang lain (masyarakat) dan dengan lingkungan.

Keseimbangan ini sangat ditekankan oleh Allah dengan menyebut umat Islam sebagai ummatan wasathan. Ummatan wasathan adalah umat yang memiliki kebersamaan, kedinamisan dalam gerak, arah dan tujuannya serta memiliki aturan-aturan kolektif yang berfungsi sebagai penengah atau pembenar. Dengan demikian keseimbangan, kebersamaan, kemoderenan merupakan prinsip etis mendasar yang harus diterapkan dalam aktivitas maupun entitas bisnis.

Dalam al-Qur'an dijelaskan bahwa pembelanjaan harta benda harus dilakukan dalam kebaikan atau jalan Allah dan tidak pada sesuatu yang dapat membinasakan diri (QS. Al Baqarah ayat 195).

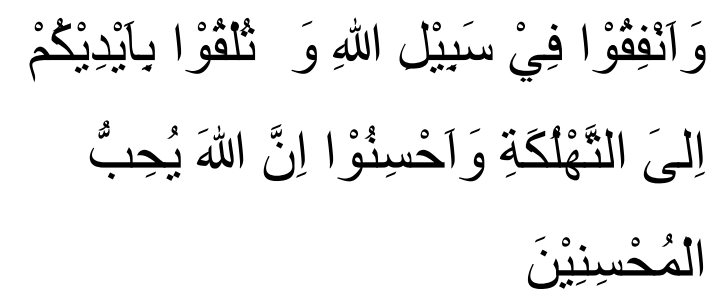

Artinya: "dan infakkanlah hartamu di jalan Allah, dan janganglah kaтu jatuhkan diri sendiri 
kedalam kebinasaan dengan tangan sendiri dan berbuat baiklah. Sungguh, Allah menyukai orang-orang berbuat baik." (Q.S. ALBaqarah: 195).

Harus menyempurnakan takaran dan timbangan dengan neraca yang benar (QS. Al Israa' ayat 35).
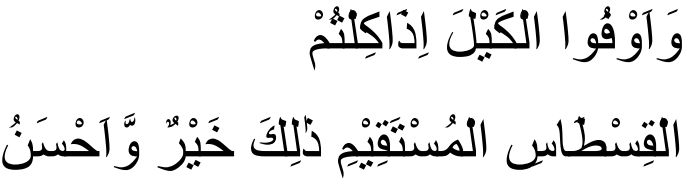

تَأَو بْلِ

Artinya: "dan sempurnakanlah takaran apabila kamu menakar, dan timbanglah dengan timbangan yang benar. Itulah yang lebih utama (bagimu) dan lebih baik akibatnya". (QS. Al Israa' ayat 35).

Dijelaskan juga bahwa ciri-ciri orang yang mendapat kemuliaan dalam pandangan Allah adalah mereka yang membelanjakan harta bendanya tidak secara berlebihan dan tidak pula kikir, tidak melakukan kemusyrikan, tidak membunuh jiwa yang diharamkan, tidak berzina, tidak memberikan kesaksian palsu, tidak tuli dan tidak buta terhadap ayat-ayat Allah.

Keseimbangan ekonomi akan dapat terwujud apabila memenuhi syarat-syarat berikut. Pertama, produksi, konsumsi dan distribusi harus berhenti pada titik keseimbangan tertentu demi menghindari pemusatan kekuasaan ekonomi dan bisnis dalam genggaman segelintir orang. Kedua, Setiap kebahagiaan individu harus mempunyai nilai yang sama dipandang dari sudut sosial, karena manusia adalah makhluk teomorfis yang harus memenuhi ketentuan keseimbangan nilai yang sama antara nilai sosial marginal dan individual dalam masyarakat. Ketiga, tidak mengakui hak milik yang tak terbatas dan pasar bebas yang tak terkenda.

3. Kehendak Bebas

Manusia sebagai khalifah di muka bumi sampai batas-batas tertentu mempunyai kehendak bebas untuk mengarahkan kehidupannya kepada tujuan yang akan dicapainya. Manusia dianugerahi kehendak bebas (free will) untuk membimbing kehidupannya sebagai khalifah. Berdasarkan aksioma kehendak bebas ini, dalam bisnis manusia mempunyai kebebasan untuk membuat suatu perjanjian atau tidak, melaksanakan bentuk aktivitas bisnis tertentu, berkreasi mengembangkan potensi bisnis yang ada.

Dalam mengembangkan kreasi terhadap pilihan-pilihan, ada dua konsekuensi yang melekat. Di satu sisi ada niat dan konsekuensi buruk yang dapat dilakukan dan diraih, tetapi di 
sisi lain ada niat dan konsekuensi baik yang dapat dilakukan dan diraih. Terdapat konsekuensi baik dan buruk oleh manusia yang diberi kebebasan untuk memilih tentu sudah harus diketahui sebelumnya sebagai suatu risiko dan manfaat yang bakal diterimanya.

Secara Islami dua pilihan yang diniatkan dan berkonsekuensi tersebut sebagai suatu pilihan di mana di satu pihak mengandung pahala yang berguna bagi diri sendiri maupun masyarakat dan di lain pihak mengandung dosa yang berpengaruh buruk bagi diri sendiri maupun bagi orang banyak

4. Pertanggungjawaban

Segala kebebasan dalam melakukan bisnis oleh manusia tidak lepas dari pertanggungjawaban yangharus diberikan atas aktivitas yang dilakukan. Kebebasan yang dimiliki manusia dalam menggunakan potensi sumber daya mesti memiliki batas-batas tertentu, dan tidak digunakan sebebas-bebasnya, melainkan dibatasi oleh koridor hukum, norma dan etika yang tertuang dalam Al-Qur'an dan Sunnah rasul yang harus dipatuhi dan dijadikan referensi atau acuan dan landasan dalam menggunakan potensi sumber daya yang dikuasai.
Tidak kemudian digunakan untuk melakukan kegiatan bisnis yang terlarang atau yang diharamkan, seperti judi, kegiatan produksi yang terlarang atau yang diharamkan, melakukan kegiatan riba dan lain sebagainya.

Apabila digunakan untuk melakukan kegiatan bisnis yang jelasjelas halal, maka cara pengelolaan yang dilakukan harus juga dilakukan dengan cara-cara yang benar, adil dan mendatangkan manfaat optimal bagi semua komponen masyarakat yang secara kontributif ikut mendukung dan terlibat dalam kegiatan bisnis yang dilakukan.

\section{E. BISNIS KOSMETIK DALAM ETIKA} BISNIS ISLAM

Bisnis kosmetik merupakan serangkaian bisnis dalam berbagai bentuk produk-produk kosmetik yang di gunakan untuk meningkatkan penampilan atau aroma tubuh manusia. Kegiatan bisnis merupakan kegiatan muamalah, yang mana umat Islam dalam berbagai aktivitasnya harus selalu berpegang dengan norma-norma ilahiyah. Kewajiban berpegang dengan normanorma ilahiyah adalah sebagai upaya untuk melindungi hak masing-masing pihak dalam bermuamalah. Secara singkat prinsip-prinsip muamalah yang telah diatur dalam hukum Islam tertuang 
dan terangkum dalam qaidah dan prinsipprinsip dasar fiqh muamalah.

Pada pokoknya semua kegiatan bisnis bernilai ibadah muamalah jika didahului dengan niatan dan harapan yang benar. Kegiatan bisnis dilakukan dengan landasan dan pedoman atau peraturan Allah di dalam Al-Qur'an dan manfaat dan kemashlahatan yang positif bagi manusia sebagai bekal hidup dan kehidupan di dunia maupun untuk hidup dan kehidupan akhirat. Semua kegiatan dengan segala niat dan harapan di atas akan dapat dibenarkan aatau sah adanya jika:

1. Bisnis yang dilakukan adalah bisnis komoditi atau jasa yang halal.

2. Cara-cara yang dilakukan adalah cara yang dapat dibenarkan syari' at Islam

3. Tujuan bisnis yang dicapai benar dan jelas secara syari' ah. ${ }^{14}$

Qaidah paling dasar dan paling utama yang menjadi dasar muamalah adalah qaidah yang sangat terkenal dan disepakati oleh ulama empat mazhab:

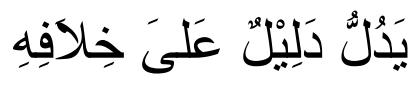

Artinya: "Hukum dasar muamalah adalah diperbolehkan, sampai ada dalil yang melarangnya". ${ }^{15}$

${ }^{14}$ Muslich, Etika Bisnis Islami..., h. 47-48.

${ }^{15}$ Imam Mustofa, Figh Muamalah Kontemporer, (Jakarta: PT. Raja Grapindo Persada, 2016), h. 10
Berdasarkan pemaparan di atas, maka pada dasarnya manusia diberi kebebasan untuk mengembangkan model muamalah. Implikasi dari kebebasan dalam hal muamalah adalah kebebasan dalam inovasi mengembangan produk. Pengembangan model transaksi dan produk dalam konteks ekonomi Islam tetap harus mempunyai landasan dan dasar hukum yang jelas dari perspektif fiqh. Agar muamalah tidak berkembang liar keluar dari jalur dan rambu-rambu telah ditetapkan syar'i atau Allah SWT, maka ulama' membangun Dabit atau prinsip-prinsip dasar fiqh muamalah dalam Islam. Dabit fiqh muamalah yang paling utama adalah: ${ }^{16}$

1. Prinsip pertama

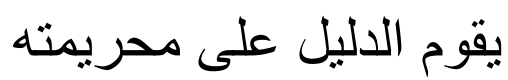
"Hukum dasar muamalah adalah halal, sampai ada dalil yang mengharamkannya".

2. Prinsip kedua

"Hukum dasar syarat-syarat dalam muamalah adalah halal"

3. Prinsip ketiga

"Larangan berbuat zalim"

4. Prinsip keempat

16 Imam Mustofa, Fiqh Muamalah Kontemporer ..., h. 11 
Jadi dalam kegiatan bisnis kosmetik

"Larangan melakukan penipuan"

5. Prinsip kelima

"Larangan riba"

6. Prinsip keenam

"Larangan Maisir (tindakan gambling)"

7. Prinsip Ketujuh Kejujuran dan Dapat Dipercaya

8. Prinsip kedelapan (sadd al-Dzari'ah)

Dzari'ah secara bahasa berarti perantara, dalam konteks hukum Islam, Dzari'ah berarti perantara atau sarana yang dapat menimbulkan kemadharatan kerugian. Secara lebih luas, dalam hal ini Dzari'ah berarti sarana atau perantara yang secara lahiriah hukumnya mubah, namun bisa mendatangkan kemadharatan yang diharamkan. $^{17}$

Praktek bisnis atau jual beli, Islam menganjurkan agar orang yang terjun dalam dunia usaha di wajibkan mengeahui hal-hal yang dapat mengakibatkan bisnis atau jual beli itu sah atau tidak (fasid). Ini di maksudkan agar mu'amalat berjalan dengan sah dan segala sikap tindakannya jauh dari kerusakan yang tidak di benarkan. ${ }^{18}$

18 As-Sayyid Sabiq, fiqih Assunah, terj. A.Marzuki (Bandung):Ma'arif,1988) h.12 pada dasarnya adalah boleh sesuai dengan kaidah muamalah, Hal ini sebagaimana hukum asal dari pada memanfaatkan sesuatu adalah mubah, berkaitan dengan kosmetik, Islam tidak menghendaki adanya sesuatu yang membahayakan bagi penggunanya karena sesuatu yang membahayakan adalah terlarang.

Namun pada prakteknya bisnis kosmetik juga banyak pedagang kosmetik abal-abal yang memberikan penawaran menarik bagi konsumen dengan menggunakan nama bahwa produk tersebut asli dari dokter, kosmetik yang tidak layak edar karena zat-zat yang terkandung dalam kosmetik tersebut mengandung bahan-bahan yang berbahaya seperti mercuri, Hidrokinon, serta komposisi dari bahan-bahan yang tidak halal.

Beberapa bentuk jual beli yang dilarang adalah karena brang najis yang merugikan pasar sehingga kehilangan sifat taqawwum dan haliyah) yaitu diantaranya: khamr, babi, darah yang mengalir, serta bangkai (diantaranya, setiap binatang yang tidak disembelih sesuai aturan syariat. ${ }^{19}$ Hal ini sangat bersebrangan dengan konsep maqasid

${ }^{19}$ Oni Syahroni , dan Adiwarman A Karim, Maqasid Bisnis dan Keuangan Islam: Sintesis Fikih dan Ekonomi, (Jakarta: PT. Raja Grafindo Persada, 2016), cet.ke-2, h. 252 
alsyariah dalam ekonomi Islam, terutama yang berkaitan dengan produksi. Seorang produsen ketika memproduksi suatu barang/jasa hendaknya selalu mengingat keamanan produk/ jasa yang mereka tawarkan. Karena aktivitas produksi bukan hanya berkaitan dengan profit dan benefit, melainkan juga berkaiatan dengan penegakkan kemashlahatan masyarakat. ${ }^{20}$ Maslahat adalah target dari disyariatkannya hukumnya Islam kepada manusia dan alam semesta ini, yaitu memberikan manfaat, memenuhi seluruh hajat manusia, dan menolak setiap bahayat terhadap manusia. ${ }^{21}$

Upaya pencegahan (al-wiqayah), selalu digalakkan oleh Islam kaitannya menghindari keruskan. Beberapa kerusakan yang terjadi akibat ketidakjelasn informasi misalnya, bisa menyebabkan rusaknya suatu transaksi. Sejatinya dalam jual beli, baik produsen, konsumen, maupun distributor mendapatkan keuntungan dengan cara yang baik, sehingga berimplikasi pada kehalalan produk yang dipasarkan. ${ }^{22}$

Jadi dalam Bisnis kosmetik ini juga harus memperhitungkan aspek keamanan

\footnotetext{
${ }^{20}$ Ika Yunia Fauzia, dan Abdul Kadir Riyadi, Prinsip Dasar Ekonomi Islam: Prespektif Ekonomi Islam, (Jakarta: Kencana Prenadamedia Group, 2014), h.264

${ }^{21}$ Oni Syahroni, Ushul Fiqh Muamalah: kaidah-kaidah Ijtihad dan Fatwa dalam Ekonomi Islam, (Jakarta: PT. Raja Grafindo Persada, 2017) 106

${ }^{22}$ Ika Yunia Fauzia, dan Abdul Kadir Riyadi...., 253
}

dan kesehatan dalam produk yang dipasarkan serta tidak ada pemalsuan informasi (informasi yang tidak benar) dalam mememasarkan poduk. Adanya ketidak mampuan konsumen dalam menerima informasi dan keragaman produk yang dipasarkan, membuat konsumen akan sangat mudah terkena dampak yag membahayakan akibat efek samping yang timbuk dari pemakaian produk.

Promosi menurut etikanya adalah kebenaran dan kejujuran obyetivitas pesan faktual yang disampaikan. Secara etis yang merupakan kata kunci untuk membangun image kepercayaan pada pada pasar atau konsumen adalah seberapa jauh obyektivitas atas kejujuran sesuai dengan kualifikasi dari barang atau jasa yang ditawarkab atau dipromosikan. Jika seandainya tidak menekan paa obyektivitas atau kebenaran dan kejujuran maka bagaimana image dapat terbangun di masyarakat bahwa barag ditawarkan adalah sebuah fakta dan kenyataan. Jika prinsip kebenaran dan keujuran ini dijadikan landasan dalam menyampaikan promosi maka dipastikan dijamin bahwa image positif akan terbangun loyalitasnya untuk melakukan pembelian pada barang yang diinformasikan secra obyektif atau jujur 
tersebut. Hal inilah yang sesuai dengan prinsip etika promosi di dalam Islam. ${ }^{23}$

Ibnu Taimiyah pernah mengatakan dalam bukunya al-Hisbah fi al Islam, wali al-hisbah hendaknya menghukum para ahli kimia yang pandai memalsukan mata uang, barang-barang perhiasan, wangi-wangian, dan lain sebagainya. Menarik untuk kemudian dikaji disini, pada masa Ibn Taimiyah dan Ibn Qayyim al Jawziyyah, sudah terdapat barngbarang palsu produk kimiawi yang kemudian dipasarkan dengan informasi palsu bahwa barang-barang tersebut asli. $^{24}$

Bisnis kosmetik memang mempunyai dampak positif dan negatifnya, diantaranya dampak positif dari bisnis kosmetik yaitu meningkatkan penghasilan pendapatan bagi pedagang kosmetik, dan menumbuhkan kepercayaan diri bagi konsumen, meperbaiki penampilan, merubah warna kulit. Namun di balik itu juga terdapat dampak negatif pada Bisnis kosmetik apabila kosmetik-kosmetik yang di perjual belikan tersebut merupakan kosmetik yang tidak layak edar karena zat-zat yang terkandung dalam kosmetik tersebut mengandung bahan-bahan yang berbahaya seperti mercuri, dan Hidrokinon. Bisnis kosmetik tersebut

\footnotetext{
${ }^{23}$ Muchlich...., h. 107

${ }^{24}$ Ika Yunia Fauzia, dan Abdul Kadir Riyadi...., 255
}

berdampak pada pengguna atau konsumen kosmetik yaitu menimbulkan efek seperti iritasi, timbulnya bintikbintik kemerah-merahan flek-flek hitan, jerawat, serta gangguaan kesehatan lainnya apabila penggunaan janggka panjang seperti gagal ginjal dan beberapa dampak negatif lainnya.

Praktek Bisnis seperti di atas merupakan praktek mal-bisnis. Praktek mal-bisnis di sini adalah mencakup semua perbuaan bisnis yang tidak baik, jelek, (secara moral) terlarang, membawa akibat kerugian bagi pihak yang lain, maupun yang meliputi aspek hukum (pidana) yang disebut business crimes atau business tort. Business crimes adalah tindak pidana dalam bisnis yaitu perbuatan-perbuatan tercela yang dilakukan oleh businessman atau pegawai suatu bisnis baik untuk keuntungan bisnisnya maupun yang merugikan bisnis pihak lain. Adapun business tort adalah perbuatan yang tidak terpuji yang dilakukan oleh usahawan yang merupakan pelanggaran terhadap pengusaha lain. Di Indonesia kedua jenis perbuatan ini dianggap sebagai kejahatan bisnis. $^{25}$

Mencari landasan praktek mal-bisnis, diasumsikan seperti mencari dan mengenali sumber penyakit. Al-Qura'an sebagai sumber nilai, tentunya 
memberikan nilai-nilai prinsipil untuk mengenali perilaku-perilaku yang bertentangan dengan nilai-nilai AlQur'an yang sesuai dengan misinya. Terma al-bathil, al-fasad, dan azh-zhalim sebagai landasan-landasan atau muara perbuatan-perbuatan yang bertentangan dengan nilai yang dibolehkan atau dianjurkan Al-Qur'an khususnya dalam dunia bisnis. Ketiga prinsip di atas sebagai tolak ukur menilai dan menetapkan suatu bisnis termasuk praktek mal-bisnis atau tidak.

Menurut a-Maraghi, al-batil berasal dari al-buthlu dan al-buthlan, berarti kesia-siaan dan kerugian, yang menurut syara' mengambil harta tanpa pengganti hakiki dan tanpa keridhaan dari pemilik harta yang diambil tersebut. Al-fasad sendiri yang berasal dari kata dasar $f-s-d$ berarti kerusakan, kebusukan, yang tidak sah, yang batal, lawan dari perbaikan, atau sesuatu yang keluar dari keadilan baik sedikit maupun banyak, atau juga kerusakan yang terjadi pada diri manusia, benda dan lain-lain. ${ }^{26} \mathrm{Az}$-zhalim berasal dari kata azh-zhulm yang bermakna meletakkan sesuatu tidak pada tempatya, ketidak adilan, penganiayaan, tindakan sewenang-wenang, dan kegelapan.

Dengan demikian dari pemahaman al-bathil dihubungkan dengan pengertian hakikat bisnis, bahwa salah satu landasan praktek mal-bisnis adalah setiap praktek bisnis mengandung unsur kebatilan baik sedikit maupun banyak, tersembunyi maupun terang-tarangan, dapat menimbulkan kerugian secara material maupun immateri baik sipelaku, pihak lain maupun masyarakat. Dapat menimbulkan ketidak seimbangan dan ketidak adilan. Menimbulkan akibatakibat moral maupun akibat hukum yang mengikutinya, baik menurut hukum agama maupun dan hukum positif. Akibat-akibat demikian bukan hanya dari tinjauan kehidupan dunia, melainkan pula semua yang berefek buruk akibatnya bagi kehidupan kelak.

\section{F. KESIMPULAN}

Berdasarkan pembahasan yang telah dipaparkan, dapat disimpulkan bahwa Bisnis kosmetik merupakan serangkaian bisnis dalam berbagai bentuk produkproduk kosmetik yang di gunakan untuk meningkatkan penampilan atau aroma tubuh manusia. Jadi dalam kegiatan bisnis kosmetik pada dasarnya adalah boleh sesuai dengan kaidah muamalah, Hal ini sebagaimana hukum asal dari pada memanfaatkan sesuatu adalah mubah, berkaitan dengan kosmetik, Islam tidak menghendaki adanya sesuatu yang membahayakan bagi penggunanya karena sesuatu yang membahayakan adalah terlarang.

\footnotetext{
${ }^{26}$ Muhammad, Etika Bisnis Islami..., h. 228.
} 
Namun pada prakteknya bisnis kosmetik juga banyak kosmetik yang tidak layak edar karena zat-zat yang terkandung dalam kosmetik tersebut mengandung bahan-bahan yang berbahaya seperti mercuri, dan Hidrokinon, serta memberikan penawaran menarik bagi konsumen dengan menggunakan nama bahwa produk tersebut asli dari dokter. Kometik ini memberikan dampak negatif yaitu: menimbulkan efek seperti iritasi, timbulnya bintik-bintik kemerah-merahan flek-flek hitan, jerawat, serta gangguaan kesehatan lainnya apabila penggunaan janggka panjang seperti gagal ginjal dan beberapa dampak negatif lainnya. Praktek Bisnis seperti di atas merupakan praktek mal-bisnis, yang mengandung unsur albathil, al-fasad, dan azh-zhalim. Hal ini dapat menimbulkan kerugian secara material maupun immateri baik sipelaku, pihak lain maupun masyarakat. Setiap kegiatan bisnis hendaknya sesuai dengan landasan normatif etika bisnis dalam Islam bersumber dari al-Qur'an dan Sunnah Nabi Muhammad SAW.

\section{DAFTAR PUSTAKA}

Alma, Buchari dan Donni Juni Priansa, Manajemen Bisnis Syariah, Bandung : Alfabeta 2009

Badroen, Faisal, dkk, Etika Bisnis dalam Islam, Jakarta: Kencana, 2007
Budi Untung, Hukum dan Etika Bisnis, Yogyakarta :Penerbit CV Andi Offset, 2012

Fauzia, Ika Yunia, dan Abdul Kadir Riyadi, Prinsip Dasar Ekonomi Islam: Prespektif Ekonomi Islam, Jakarta: Kencana Prenadamedia Group, 2014

Gunawan Widjajadan Ahmad yani, Hukum Perlindungan Konsumen, Jakarta: PT.Gramedia Pustaka Utama

Manullang, M, Pengantar Bisnis, Yogyakarta : Gadjah Mada University Press 2002

Muhammad, Etika Bisnis Islami, Yogyakarta: UPP AMP YKPN, 2004

Muslich, Etika Bisnis Islami, Yogyakarta:Ekonosia, 2004

Mustofa, Imam, Fiqh Muamalah Kontemporer, Jakarta: PT. Raja Grapindo Persada, 2016

Poerwadarminta, Kamus Umum Bahasa Indonesia, cet-III Jakarta:PT Intan Parawira 2003

Qamaruddin Awwam, Fiqh Wanita, Jakarta: Cerdas Interaktif, 2017

Sabiq, As-sayyid, Fiqih Assunah, terj. A.Marzuki, Bandung:Ma'arif,1988

Syahroni, Oni, dan Adiwarman A Karim, Maqasid Bisnis dan Keuangan Islam: Sintesis Fikih dan Ekonomi, Jakarta: PT. Raja Grafindo Persada, 2016

Syahroni, Oni, Ushul Fiqh Muamalah: kaidah-kaidah Ijtihad dan Fatwa dalam Ekonomi Islam, (Jakarta: PT. Raja Grafindo Persada, 2017

Yusanto, Muhammad Ismail dan Muhammad Karebet Widjajakusuma. 2002. Menggagas Bisnis Islami, Jakarta: Gema Insani Press 2002 